\title{
Lecture Notes
}

\section{in Business Information Processing}

\section{Series Editors}

Wil van der Aalst

Eindhoven Technical University, Eindhoven, The Netherlands

John Mylopoulos

University of Trento, Trento, Italy

Michael Rosemann

Queensland University of Technology, Brisbane, QLD, Australia

Michael J. Shaw

University of Illinois, Urbana-Champaign, IL, USA

Clemens Szyperski

Microsoft Research, Redmond, WA, USA 
More information about this series at http://www.springer.com/series/7911 
Ulrika Lundh Snis (Ed.)

\section{Nordic Contributions in IS Research}

7th Scandinavian Conference

on Information Systems, SCIS 2016 and IFIP8.6 2016 Ljungskile, Sweden, August 7-10, 2016 Proceedings 


\section{Editor}

Ulrika Lundh Snis

Department of Economics and IT

Hogskolan Vast

Uddevalla

Sweden

(C) IFIP International Federation of Information Processing 2016. These papers were published with kind permission. All rights reserved. Who is in Control in Crowdsourcing Initiatives? An Examination of the Case of Crowdmapping - A.R. Shahid and A. Elbanna, Co-creation and Fine-Tuning of Boundary Resources in Small-Scale Platformization - A.S. Islind, T. Lindroth, U.L. Snis and C. Sørensen, Learning for Professional Competence in an IS Context - P.M. Bednar and C. Welch, ICT and Learning Usability at Work - Challenges and Opportunities for Physicians in Everyday Practice - H.V. Hult, K. Byström and M. Gellerstedt

\section{ISSN $1865-1348$}

ISSN 1865-1356 (electronic)

Lecture Notes in Business Information Processing

ISBN 978-3-319-43596-1

ISBN 978-3-319-43597-8 (eBook)

DOI 10.1007/978-3-319-43597-8

\section{Library of Congress Control Number: 2016947769}

\section{(C) Springer International Publishing Switzerland 2016}

This work is subject to copyright. All rights are reserved by the Publisher, whether the whole or part of the material is concerned, specifically the rights of translation, reprinting, reuse of illustrations, recitation, broadcasting, reproduction on microfilms or in any other physical way, and transmission or information storage and retrieval, electronic adaptation, computer software, or by similar or dissimilar methodology now known or hereafter developed.

The use of general descriptive names, registered names, trademarks, service marks, etc. in this publication does not imply, even in the absence of a specific statement, that such names are exempt from the relevant protective laws and regulations and therefore free for general use.

The publisher, the authors and the editors are safe to assume that the advice and information in this book are believed to be true and accurate at the date of publication. Neither the publisher nor the authors or the editors give a warranty, express or implied, with respect to the material contained herein or for any errors or omissions that may have been made.

\section{Printed on acid-free paper}

This Springer imprint is published by Springer Nature The registered company is Springer International Publishing AG Switzerland 


\section{Preface}

The 7th Scandinavian Conference on Information Systems, SCIS 2016, hosted in Ljungskile, Sweden, was jointly organized by the LINA (Learning in and for the New Workplace) research center at University West and the Digital group (Learning in a Digitalized Region) of University West and the University of Gothenburg.

SCIS 2016 highlighted the digitalization of society, that has proceeded and entered almost all aspects of our lives. Digitalization refers to the way in which many domains of social life are reshaped around digital communication and media infrastructures, and what constitutes a worker, a student, and a citizen in a digitalized society as it has consequently evolved to be. In parallel, new research interests concerning the use and design of digital services and devices have emerged. The 7th SCIS conference had the theme "Living in the Cloud" emphasizing three aspects in particular; First, it refers to "the cloud" as the increasingly ubiquitous digital data storage "up there," which makes digital information appear to be detached from physical location and thus available anytime, anywhere, connecting everything with everyone. This has a profound effect on contemporary practices and on the way humans construct and perceive our understanding of information and information systems. Second, it refers to how boundaries appear blurred and vague and it is unclear where things start and end. For example, digital services today are often open-ended systems, resembling containers or infrastructures, which are changed by users during use as a dynamic evolution. Finally, it illustrates the tension between contrasting aspects related to the consequences of digitalization, such as how to handle the diffusion of private versus professional roles, relations, services, or information systems and how to balance benefits versus challenges of being constantly connected.

A total of 25 manuscripts were submitted to the conference. The evaluation was a careful double-blind review process with at least two reviewers for each paper. Finally, nine papers were accepted for presentation at the conference and in these proceedings (with an acceptance rate of $36 \%$ ).

SCIS 2016 invited three keynote speakers: Margunn Aanestad from Oslo University (Norway) Carsten Sørensen from the London School of Economics and Political Science (UK), and Viktori Kaptelinin from Umeå University (Sweden).

As in previous years, the SCIS conference was arranged in conjunction with the Information Systems Research Conference in Scandinavia, known as the IRIS conference, which began in 1978 and which with its 39th annual gathering is the oldest consecutive information systems conference in the world. IRIS is today organized as a working seminar between established researchers and doctoral students. The young researchers and their interest in information systems boded well for shaping the future of the field.

We would like to thank the supporters and sponsors of this conference. We are grateful to all those people who contributed to this conference, whether as organizers, Program Committee members, reviewers, scientific contributors, or otherwise. Finally, 
we would like to extend our warmest thanks to all those volunteers who contributed in so many ways to making this conference a successful and memorable event.

May 2016

Martin Gellerstedt

Ulrika Lundh Snis

Johan Lundin

Lena Pareto

Lars Svensson

Dick Stenmark 


\section{Organization}

\section{Conference Chairs}

Lena Pareto

University West, Sweden

Lars Svensson

University West, Sweden

\section{Program Chair}

Ulrika Lundh Snis

University West, Sweden

\section{Proceedings Chairs}

Johan Lundin

University of Gothenburg, Sweden

Ulrika Lundh Snis

University West, Sweden

\section{Cloud Chairs}

Anna Sigridur Islind

University West, Sweden

Tomas Lindroth

Gothenburg University, Sweden

\section{Web Chair}

Stefan Nilsson

University West, Sweden

\section{Sponsorship Chairs}

Martin Ljungdal-Eriksson

University West, Sweden

Monika Hattinger

Ann Svensson

University West, Sweden

University West, Sweden

\section{Program Committee}

Ivan Aaen

Margunn Aanestad

Magnus Bergqvist

Fredrik Bergstrand

Erik Borglund

Morten Brandrup

Tone Bratteteig

Katerina Cerna

Esbjörn Ebbesson
Aalborg University, Denmark

University of Oslo, Norway

Halmstad University, Sweden

University of Gothenburg, Sweden

Mid Sweden University, Sweden

Roskilde University, Denmark

University of Oslo, Norway

University of Gothenburg, Sweden

Halmstad University, Sweden 
Sisse Finken

Martin Gellerstedt

Kerstin Grundén

Amir Haj-Bolouri

Monika Hattinger

Ilona Heldal

Ola Henfridsson

Harald Holone

Karin Högberg

Netta Iivari

Will Jobe

Lars-Olof Johansson

Leona Johansson-Bunting

Viktor Kaptelinin

Joakim Karlsson

John Krogstie

Arto Lanamäki

Jonas Landgren

Susanne Lindberg

Tomas Lindroth

Berner Lindström

Jesper Lund

Mona Lundin

Anita Mirjamdotter

Judith Molka-Danielsen

Christina Mörtberg

Stefan Nilsson

Livia Norström

Urban Nuldén

Jacob Nørbjerg

Henry Oinas-Kukkonen

Torbjörn Ott

Samuli Pekkola

Esko Penttinen

Noora Pinjamaa

Tero Päivärinta

Ada Scupola

Sofia Serholt

Anna Sigridur Islind

Maria Spante

Dick Stenmark

Susanne Stigberg

Frantisek Sudzina

Reima Suomi

Ann Svensson
Linneaeus University, Sweden

University West, Sweden

University West, Sweden

University West, Sweden

University West, Sweden

University College Bergen, Norway

Warwick Business School, UK

Østfold University College, Norway

University West, Sweden

University of Oulu, Finland

University West, Sweden

University West, Sweden

University of Gothenburg, Sweden

Umeå University, Sweden

Østfold University College, Norway

Norwegian University of Science and Technology, Norway

University of Oulu, Finland

Chalmers University of Technology, Sweden

Halmstad University, Sweden

University West, Sweden

University West, Sweden

Halmstad University, Sweden

University West, Sweden

Linneaeus University, Sweden

Molde University College, Norway

Linneaeus University, Sweden

University West, Sweden

University West, Sweden

University of Gothenburg, Sweden

Copenhagen Business School, Denmark

University of Oulu, Finland

University of Gothenburg, Sweden

Tampere University of Technology, Finland

Helsinki School of Economics, Finland

Aalto University, Finland

Luleå University of Technology, Sweden

Roskilde University, Denmark

University of Gothenburg, Sweden

University West, Sweden

University West, Sweden

University of Gothenburg, Sweden

VUT, Austria

Aalborg University, Denmark

University of Turku, Finland

University West, Sweden 
Carsten Sørensen

Michel Thomsen

Virpi Tuunainen

Tuure Tuunanen

Kristian Tørning

Helena Vallo Hult

Sara Willermark

Thomas Winman

Lena-Maria Öberg

Christian Östlund
London School of Economics and Political Science, UK

Halmstad University, Sweden

Aalto University School of Business, Finland

University of Jyväskylä, Finland

Danish School of Media and Journalism, Denmark

University West, Sweden

University West, Sweden

University West, Sweden

Mid Sweden University

University West, Sweden 


\section{Contents}

\section{SCIS 2016}

Evolution of the Blog Genre: The Emergence of the Corporate

Personal Blog. . . . . . . . . . . . . . . . . . . .

Noora Pinjamaa

'It Has to Be Useful for the Pupils, of Course' - Teachers as Intermediaries

in Design with Children. . . . . . . . . . . . . . . . . . . . 16 Netta Iivari and Marianne Kinnula

Sound Bubbles for Productive Office Work . . . . . . . . . . . . . . . 29 Martin Ljungdahl Eriksson and Lena Pareto

Extending e-Health Infrastructures with Lightweight IT . . . . . . . . . 43 Egil Øvrelid and Bendik Bygstad

The Ambivalent Characteristics of Connected, Digitised Products:

Case Tesla Model S . . . . . . . . . . . . . . . . . . . . . 57 Antti K. Lyyra and Kari M. Koskinen

Net Up Your Innovation Value....................... 70 Jan Pries-Heje and Magnus Rotvit Perlt Hansen

Sustaining Sustainability: Investigating the Long-Term Effects of a Sustainability Initiative . . . . . . . . . . . . . . . . . .

Fredrik Bengtsson and Pär J. Agerfalk

A Boundary Practice Perspective on Co-creation of ICT Innovations....... . Lars-Olof Johansson, Ulrika Lundh Snis, and Lars Svensson

The Roles of Conference Papers in IS: An Analysis of the Scandinavian

Conference on Information Systems

Arto Lanamäki and John Stouby Persson 


\section{Preface}

This book contains the proceedings of the IFIP Working Group 8.6 Conference, which was organized by University West and held in Ljungskile, Sweden, in August 2016.

The aim of the IFIP Working Group 8.6 is to foster the understanding of and improve research in practice, methods, and techniques involved in the transfer and diffusion of information technology within systems that are developed and in the development process itself.

The theme of the 2016 conference was "Diffusion of IS for Learning New Practices." The theme aims to encourage research into the challenges for learning and competent acting with regards to diffusion, adoption, and implementation of various forms of information technology. We aimed to address issues related to learning new practices from both the organizational and societal perspectives traditionally covered by IFIP Working Group 8.6.

A total of 11 manuscripts were submitted for the conference. The Program Committee undertook a double-blind reviewing process with at least two reviews for each paper. The four chairs used the reviews as well as their own evaluation to select four research papers to be included in these proceedings. Further, one panel was selected for presentation at the conference. Two keynote speakers were invited for the conference: Eleanor Wynn from Portland State University (USA) and Carsten Sørensen from the London School of Economics and Political Science (UK). Their talks were associated with the conference theme.

Our warmest thanks go to the research contributors and the sponsors of this conference, whether as organizers, Program Committee members, keynote speakers, or others. You made this a successful event.

May 2016

Ulrika Lundh Snis Anna Sigridur Islind Jan Pries-Heje Jacob Nørbjerg 


\section{Organization IFIP 8.6 2016}

\section{General Chair}

Jan Pries-Heje

Roskilde University, Denmark

\section{Program Chairs}

Ulrika Lundh Snis

Högskolan Väst, Sweden

Jacob Nørbjerg

Copenhagen Business School, Denmark

\section{Organizing Chairs}

Ulrika Lundh Snis

Högskolan Väst, Sweden

Anna Sigridur Islind

Högskolan Väst, Sweden

\section{Proceedings Chair}

Ulrika Lundh Snis

Högskolan Väst, Sweden

\section{Working Group at Högskolan Väst/University West}

Lars Svensson

Lena Pareto

Ulrika Lundh Snis

Stefan Nilsson

Anna Sigridur Islind

\section{Program Committee}

David Wainwright

Peter Bednar

Deborah Bunker

Mohamamd Hossain

Michael Myers

David Wastell

Eleanor Wynn

John Persson

Carsten Sørensen

Peter Axel Nielsen

Nancy Russo

Björn Johansson

J.P. Allen

John Venable

Amany Elbanna
Northumbria University, UK

University of Portsmouth, UK

University of Sydney, Australia

RMIT University, Australia

University of Auckland Business School, New Zealand

Nottingham University, UK

Portland State University, Intel Corporation, USA

Aalborg University, Denmark

London School of Economics, UK

Aalborg University, Denmark

Malmö University, Sweden

Lund University, Sweden

University of San Francisco, USA

Curtin University of Technology, Australia

Royal Holloway University of London, UK 
Karlheinz Kautz

Gitte Tjørnehøj Yogesh Dwivedi Tor J. Larsen Allen Higgins Brian Donnellan Ana M. Bernardos

Tom Mcmaster
University of Wollongong, Australia Aalborg University, Denmark Swansea University, UK Norwegian Business School, Norway University of Warwick, UK National University of Ireland, Maynooth, Ireland Universidad Politécnica de Madrid, Spain University of Salford, UK 


\section{Contents}

\section{IFIP 8.6 2016}

Who is in Control in Crowdsourcing Initiatives? An Examination of the Case of Crowdmapping

Abdul Rehman Shahid and Amany Elbanna

Co-creation and Fine-Tuning of Boundary Resources in Small-Scale

Platformization . . . . . . . . . . . . . . . . . . . . . . . . . .

Anna Sigridur Islind, Tomas Lindroth, Ulrika Lundh Snis, and Carsten Sørensen

Learning for Professional Competence in an IS Context. . . . . . . . . . 163

Peter M. Bednar and Christine Welch

ICT and Learning Usability at Work: Challenges and Opportunities for Physicians in Everyday Practice.

Helena Vallo Hult, Katriina Byström, and Martin Gellerstedt 